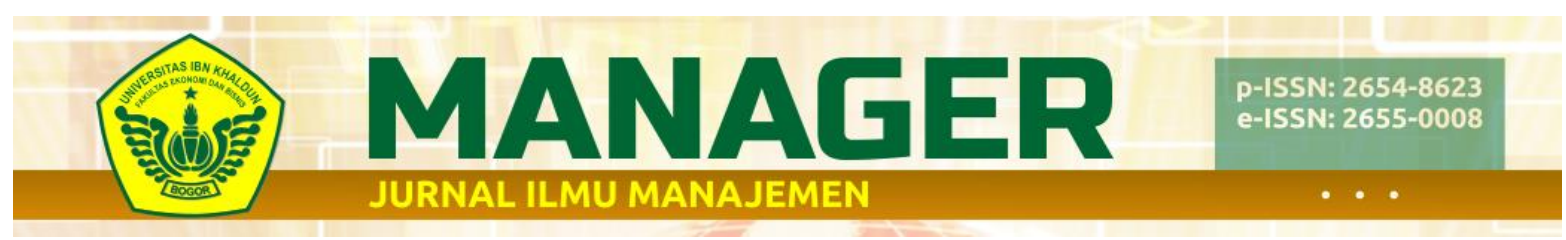

Vol. 3, No. 4, November 2020, Hal. 529-539

(c) (1) (2) http://ejournal.uikabogor.ac.id/index.php/Manager/index

\title{
PENGARUH KETERIKATAN KARYAWAN DAN KOMITMEN KERJA TERHADAP KINERJA KARYAWAN
}

\author{
Afhan Anuari, M. Azis Firdaus, Jani Subakti \\ Fakultas Ekonomi dan Bisnis Universitas Ibn Khaldun Bogor, Indonesia \\ afhan.anuari15@gmail.com, azisfirdaus@uika-bogor.ac.id,djan_2010@yahoo.com
}

\begin{abstract}
This research aims to see the effect of influence of employee engagement on employee performance at PDAM Tirta Kahuripan Bogor Regency, to see the effect of engagement on employee commitment at PDAM Tirta Kahuripan, Bogor Regency, to see the effect of work commitment on employee performance at PDAM Tirta Kahuripan Bogor Regency, and to see the effect of employee engagement on employee performance through work commitment at PDAM Tirta Kahuripan Bogor. Research This was done at PDAM Tirta Kahuripan Bogor, the respondents were employees of PDAM Tirta Kahuripan Bogor Regency who are permanent and non-permanent employees as many as 87 people from a total population of 632 people who were randomly selected. The results of the study were based on the trust test and path analysis using SPSS Statistic version 18 between employee attachment to employee performance through work commitment of 0.777. This result is due to a positive influence between employee engagement on employee performance through work commitment. Analysis using the F test, the value of $F$ count $63.880>F$ table 3.10 so that Ho is rejected (Ha accepted) and it means that there is a significant influence between employee engagement and work commitment to employee performance.
\end{abstract}

Keywords : Employee Engagement, Work Commitment and Employee Performance

\begin{abstract}
Abstrak
Penelitian ini memiliki tujuan agar dapat mengetahui pengaruh keterikatan karyawan terhadap kinerja karyawan di PDAM Tirta Kahuripan Kabupaten Bogor, agar dapat mengetahui pengaruh keterikatan karyawan terhadap komitmen kerja karyawan di PDAM Tirta Kahuripan Kabupaten Bogor, agar dapat mengetahui pengaruh komitmen kerja terhadap kinerja karyawan di PDAM Tirta Kahuripan Kabupaten Bogor, serta agar dapat mengetahui mengetahui pengaruh keterikatan karyawan terhadap kinerja karyawan melalui komitmen kerja di PDAM Tirta Kahuripan Bogor. Penelitian ini dilakukan di PDAM Tirta Kahuripan Bogor, yang menjadi responden adalah karyawan PDAM Tirta Kahuripan Kabupaten Bogor yang berstatus karyawan tetap dan tidak tetap sebanyak 87 orang dari total populasi sebanyak 632 orang yang dipilih secara acak. Hasil penelitian berdasarkan uji koefisien korelasi dan analisis jalur menggunakan SPSS Statistic versi 18 antara keterikatan karyawan terhadap kinerja karyawan melalui komitmen kerja sebesar 0,777 hasil ini memperlihatkan bahwa adanya pengaruh positif antara keterikatan karyawan terhadap kinerja
\end{abstract}


karyawan melalui komitmen kerja. Analisis menggunakan uji F, memperlihatkan $\mathrm{F}$ hitung 63,880 > F tabel 3,10 sehingga Ho ditolak (Ha diterima) dan itu berarti terdapat pengaruh yang signifikan antara keterikatan karyawan dan komitmen kerja terhadap kinerja karyawan.

Kata kunci : Keterikatan Karyawan, Komitmen Kerja dan Kinerja Karyawan

\section{Pendahuluan}

Dalam mengatasi perkembangan serta persaingan dunia usaha yang semakin ketat pada zaman sekarang ini, perusahaan diharuskan mengelola usahanya dengan lebih efektif dan juga efisien, dimana nantinya perusahaan bisa bersaing serta memiliki nilai lebih dan juga keunggulan dari para pesaingnya. Perusahaan akan mengalami kesulitan untuk maju dan sukses apabila sumber daya manusianya tidak dapat bekerjasama guna mencapai tujuan yang diinginkan. SDM memiliki peranan yang begitu dibutuhkan bagi perusahaan sebab dapat menentukan kemajuan perusahaan. Walaupun didalam perusahaan mempunyai teknologi yang canggih sarana serta prasarana yang baik dan juga memadai, akan tetapi apabila tanpa peranan sumber daya manusia, akan mengalami kesulitan dan tidak mudah bagi perusahaan mencapai tujuan yang telah direncanakan.

Di dalam persaingan yang sangat ketat perusahaan membutuhkan peranan SDM yang memiliki kualitas yang baik guna mendukung perusahaan guna mencapai kemajuan dan kesuksesan ke depannya. Karena itu perusahaan juga harus dapat melawan tantangan serta ancaman eksternal maupun internal yang dapat terjadi kapanpun dan dimanapun (Liana \& Irawati, 2014)

Komitmen kerja adalah keadaan mental yang menjadi tanda adanya pengaruh antara karyawan dengan perusahaan serta mempunyai keterikatan akan hasil seseorang untuk tetap berada atau keluar dari perusahaan. Demi suatu hal yang berhubungan positif terhadap kinerja, komitmen yang menjadi suatu sikap serta perilaku yang bisa dilihat sebagai dorongan motivasi individu dalam bekerja adalah saling berkaitan erat. Komitmen pula merupakan suatu perubahan dari bentuk keterlibatan individu atas sesuatu hal misal, keluarga, jenjang karir, area pergaulan antar individu serta semacamnya. Karena terdapatnya komitmen bisa menjadikan suatu dukungan karyawan agar bisa bekerja lebih giat dan sebaliknya bisa membuat karyawan dapat keluar dan mengabaikan tugas pekerjaannya, karena sebab suatu komitmen yang lain. Komitmen yang baik bisa memberikan semangat yang tinggi dan memberikan hasil positif atas kinerja didalam suatu tugas pekerjaan. (Trisnaningsih, 2001).

Seorang karyawan yang memiliki komitmen terhadap perusahaan tempatnya bekerja, bisa jadi memiliki cara berfikir yang lebih baik, dengan komitmen itu juga, seorang karyawan tanpa dipaksa akan mengeluarkan tenaga ekstra guna kepentingan perusahaan. Hal itu menandakan bahwa komitmen kerja mempunyai arti lebih dari hanya sebagai kesetiaan yang pasif, melainkan mempunyai pengaruh yang aktif serta kemauan karyawan guna memberikan kotribusi yang sangat berarti pada perusahaannya (Melina Taurisa \& Intan, 2012).

Kinerja ialah sesuatu yang ditunjukan oleh seorang karyawan ataupun salah satu proses yang berhubungan 
dengan tugas pekerjaan yang sudah ditentukan. Kinerja seorang karyawan yang baik dapat terlihat dari kualitas seorang karyawan itu sendiri, apabila seorang karyawan yang melaksanakan pekerjaan mempunyai keterikatan yang tinggi, baik secara psikologis, emosional, maupun fisik atas kinerja yang ada didalam suatu perusahaan (Arisca et al., 2019)

Seorang karyawan yang mempunyai keterikatan yang tinggi atas suatu pekerjaan serta perusahaannya, akan hadir serta bekerja dengan cara tertib dan teratur, mempunyai rasa memiliki atas perusahaan, mempunyai semangat dan kinerja karyawan yang tinggi. Keterikatan dapat terjadi apabila pekerjaan yang dilaksanakan sesuai minat, poin-poin pribadi, kepribadian seorang karyawan, serta keahlian yang dimiliki karyawan. Pada tingkat level seorang karyawan adanya masukan kepribadian yang bisa memengaruhi keterikatan. Keterikatan karyawan merupakan suatu usaha untuk mengarahkan kemampuan yang dimiliki karyawan supaya dapat bekerja lebih baik, konsisten serta aktif, yang bertujuan untuk pencapaian tujuan perusahaan (Nurjanah et al., 2016).

\section{Rumusan Masalah}

1. Apakah terdapat Pengaruh Keterikatan Karyawan terhadap Kinerja Karyawan PDAM Tirta Kahuripan Kabupaten Bogor?

2. Apakah terdapat Pengaruh Keterikatan Karyawan terhadap Komitmen Kerja PDAM Tirta Kahuripan Kabupaten Bogor?

3. Apakah terdapat Pengaruh Komitmen Kerja terhadap Kinerja Karyawan PDAM Tirta Kahuripan Kabupaten bogor?
4. Apakah terdapat pengaruh Keterikatan Karyawan terhadap Kinerja Karyawan melalui Komitmen Kerja PDAM Tirta Kahuripan Kabupaten Bogor?

\section{Metode Penelitian}

Metode penelitian yang dipakai dalam penelitian ini ialah metode penelitian kuantitatif dengan desain penelitian yaitu deskriptif. Adapun penelitian deskriptif ialah penelitian yang dilaksanakan guna bisa mengetahui suatu nilai variabel mandiri, baik yaitu satu variabel maupun lebih (independen) tanpa membuat kesetaraan ataupun penghubung beserta variabel yang lain. Selanjutnya penelitian kuantitatif ialah metode yang bisa disebut seperti metode suatu penelitian yang berdasarkan terhadap pandangan positivisme, digunakan untuk mengamati terhadap populasi ataupun terhadap sampel khusus, adapun cara pengambilan sampel biasanya dilaksanakan dengan cara acak, penghimpunan data menggunakan instrumen penelitian, adapun analisis datanya yaitu memiliki sifat kuantitatif ataupun statistik, yang bertujuan menguji ataupun mengukur hipotesis yang sudah ditentukan (Darna \& Herlina, 2018).

\section{Instrumen Penghimpunan Data}

Dalam penelitian ini metode penghimpunan data yang digunakan ialah dengan menyebarkan kuesioner sebanyak 87 kuesioner terhadap karyawan PDAM Tirta Kahuripan Kabupaten Bogor via Google Form, lalu kemudian datanya dikumpulkan dan diolah menggunakan aplikasi komputer yaitu SPSS Versi 18. Variabel Keterikatan Karyawan diukur dengan 10 item pertanyaan, Variabel Komitmen Kerja 10 item pertanyaan, dan 10 item pertanyaan untuk Variabel Kinerja Karyawan. 
Jawaban pada setiap pertanyaan diisi sesuai dengan Skala Likert 1 sampai 5 serta diberi skor penilaian yaitu, Skor nilai 1 yaitu Sangat Tidak Setuju / STS dengan klasifikasi (1,00 - 1,79) dengan hasil penilaian Sangat Tidak Baik. Skor nilai 2 yaitu Tidak Setuju / TS dengan klasifikasi (1,80 - 2,59) dengan hasil penilaian Tidak Baik. Skor 3 yautu Netral / Biasa / N dengan klasifikasi $(2,60-3,39)$ dengan hasil penilaian Cukup Baik. Skor 4 yaitu Setuju / S dengan klasifikasi $(3,40-4,19)$ dengan hasil penilaian Baik. Skor 5 yaitu Sangat Setuju / SS dengan klasifikasi (4,20 - 5,00) dengan hasil penilaian Sangat Baik.

Adapun hasil penilaian persepsi responden mengenai kuesioner penelitian Variabel Keterikatan Karyawan (X), Variabel Komitmen Kerja (Z), dan Variabel Kinerja Karyawan (Y) semuanya rata-rata penilaian adalah Sangat Baik.

\section{Kerangka Pemikiran}

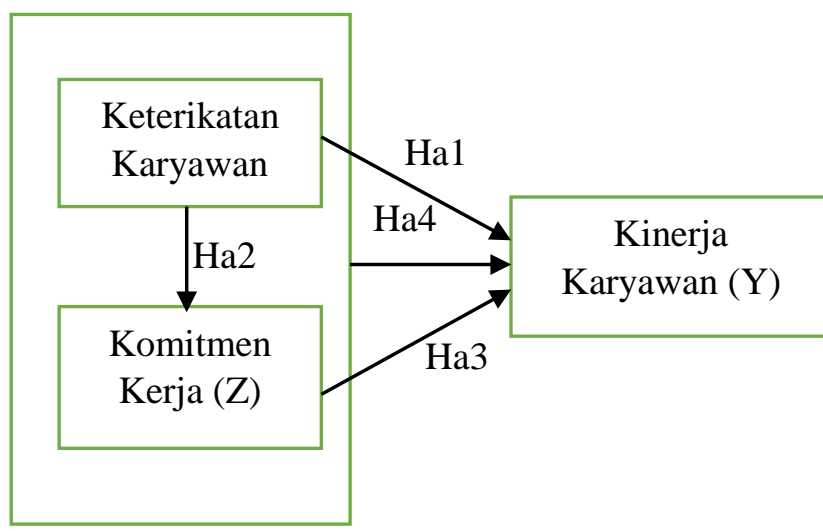

Gambar 1

Kerangka Pemikiran

Sumber : Diolah Oleh Peneliti 2020

\section{Hipotesis}

Menurut pendapat (Sugiyono, 2013, p. 70) hipotesis ialah dugaan sementara atas rumusan masalah suatu penelitian, yang mana rumusan suatu penelitian sudah dinyatakan dalam suatu bentuk kalimat pertanyaan, disebut sementara karena dugaan yang dijabarkan hanya berdasarkan terhadap suatu teori yang relevan, belum berdasarkan suatu kebenaran fakta-fakta serta bukti yang diperoleh dari hasil penghimpunan suatu data. Berikut ialah hipotesis dalam penelitian ini antara lain :

Ho1 = Diduga Keterikatan Karyawan (X) tidak memengaruhi Kinerja Karyawan (Y). Ha1 = Diduga Keterikatan Karyawan (X) memengaruhi Kinerja Karyawan (Y).

Ho2 = Diduga Keterikatan Karyawan (X) tidak memengaruhi Komitmen Kerja (Z).

Ha2 = Diduga Keterikatan Karyawan (X) memengaruhi Komitmen Kerja (Z).

Ho3 = Diduga Komitmen Kerja (X) tidak memengaruhi Kinerja Karyawan (Y).

Ha3 = Diduga Komitmen Kerja (Z) memengaruhi Kinerja Karyawan (Y).

Ho4 = Diduga Keterikatan Karyawan (X) tidak memengaruhi Kinerja Karyawan (Y) melalui Komitmen Kerja (Z).

Ha4 = Diduga Keterikatan Karyawan (X) memengaruhi Kinerja Karyawan (Y) melalui Komitmen Kerja (Z).

\section{Hasil dan Pembahasan Penelitian} Uji Validitas dan Reliabilitas

Untuk pengujian validitas diperoleh hasil bahwasanya semua variabel yaitu Keterikatan Karyawan, Komitmen Kerja dan Kinerja Karyawan mempunyai nilai $r_{\text {hitung }}>r_{\text {tabel }}(0,213)$. Sehingga dapat disimpulkan bahwasanya seluruh item pertanyaan variabel Keterikatan Karyawan, Komitmen Kerja dan Kinerja Karyawan yaitu valid, untuk dipakai sebagai instrumen didalam suatu pengamatan atau setiap pertanyaan yang diajukan bisa dipakai guna menguji setiap variabel yang akan diteliti.

Selanjutnya, pengujian reliabilitas diperoleh hasil pengujian semua variabel 
Keterikatan yaitu, Keterikatan Karyawan, Komitmen Kerja dan Kinerja Karyawan mempunyai nilai Cronbach's Alpha > 0,60 sehingga bisa disimpulkan bahwasanya semua item pertanyaan Reliabel dan bisa diterima.

\section{Analisis Deskriptif}

\section{Analisis Deksriptif Terhadap} Variabel Keterikatan Karyawan (X)

Variabel Keterikatan Karyawan (X) mempunyai nilai terkecil sejumlah 30 serta nilai terbesar sejumlah 50 dengan nilai rata-ratanya sejumlah 42,95 serta standar deviasinya (tingkat sebaran datanya) sebesar 4,710.

\section{Analisis Deskriptif Terhadap Variabel Komitmen Kerja (Z) \\ Variabel Komitmen Kerja (Z)} mempunyai nilai terkceil sejumlah 31 serta nilai terbesar sejumlah 50 dengan nilai rata-ratanya sejumlah 43,46 serta standar deviasinya (tingkat sebaran datanya) sebesar 4,702.

\section{Analisis Deskriptif Terhadap Kinerja Karyawan (Y)}

Variabel Kinerja Karyawan (Y) mempunyai nilai terkecil sejumlah 35 serta nilai terbesar sejumlah 50 dengan nilai rata-ratanya sejumlah 44,66 serta standar deviasinya (tingkat sebaran datanya) sebesar 3,991.

\section{Uji Normalitas}

Menurut (Imam, 2009, p. 129) uji normalitas memiliki tujuan guna menguji apakah dalam model variabel pengganggu, model regresi atau residual mempunyai distribusi normal. Seperti diketahui bahwasanya pengujian $t$ serta pengujian $F$ memperhitungkan bahwasanya nilai residual dengan mengikuti distribusi secara normal.

Berdasarkan data yang diolah menggunakan aplikasi komputer bisa diketahui bahwa nilai signifikan atau (Asymp. Sig. 2-tailed) Keterikatan Karyawan (X) sebesar 0,601 > 0,05 Komitmen Kerja $(Z)$ sebesar 0,146>0,05 dan Kinerja Karyawan (Y) sebesar 0,251 > 0,05. Bisa disimpulkan maka hasilnya adalah data berdistribusi secara normal.

\section{Uji Linearitas}

Menurut (Hadi, 2004, p. 13) uji linearitas dipakai guna bisa mengetahui keterkaitan antara variabel dependen / terikat serta variabel independen / bebas memiliki sifat linear atau tidak secara siginifikan. Adapun klasifikasi yang dipakai ialah apabila nilai signifikansi defiation from linearity $>0,05$ maka bisa diartikan bahwasanya antara variabel indepenen / bebas serta variabel terikat / dependen adanya hubungan atau keterkaitan yang linear.

Berdasarkan hasil pengujian linearitas menggunakan aplikasi komputer yaitu untuk variabel Keterikatan Karyawan (X) ialah bahwa nilai regresi variabel Keterikatan Karyawan (X) dengan variabel Kinerja Karyawan (Y) terhadap deviation from linearity sebesar 1,344 dan nilai signifikansi sejumlah 0,193 > 0,05. Maka dapat disimpulkan bahwa antara variabel Kinerja Karyawan (Y) memiliki hubungan atau keterkaitan yang linear terhadap variabel Keterikatan Karyawan (X).

Selanjutnya, hasil uji Linearitas untuk variabel Komitmen Kerja (Z) terhadap kinerja Karyawan (Y) bahwa nilai regresi variabel Komitmen Kerja (Z) dengan variabel Kinerja Karyawan (Y) pada deviation from linearitysebesar 0,806 dan nilai signifikansi sejumlah 0,667 > 0,05 . Maka bisa disimpulkan bahwa antara variabel Kinerja Karyawan (Y) memiliki hubungan yang linear terhadap variabel Komitmen Kerja (Z). 


\section{Uji Multikolinearitas}

Menurut (Imam, 2009, p. 105) uji multikolinearitas mempunyai tujuan guna menguji apakah model regresi ditemukan adanya korelasi antar variabel bebas (independen). Model regresi yang baik ialah seharusnya tidak terjadi korelasi antar variabel bebas. Toleransi mengukur variabilitas variabel bebas yang terpilih dengan tidak dijabarkan dengan variabel bebas / independen lain. Maka, untuk nilai toleransi yang kecil sama dengan nilai VIF (Variance Inflation Factor) tinggi (karena VIF $=1 /$ Toleransi). Nilai cutoff yang umum digunakan untuk memperlihatkan adanya multikolinearitas ialah nilai Toleransi $<10$ atau sama dengan nilai VIF $>10$.

Dengan demikian hasil pengujian multikolinearitas menggunakan aplikasi komputer bisa diketahui hasil analisis multikolinearitas tidak terdapat multikolinearitas yang berarti, antara masing-masing variabel independen dalam model regresi, karena:

1. Nilai toleransi yaitu sebesar $0,530>$ dari 0,10

2. Nilai VIF yaitu sebesar $1,887<$ dari 10,00

\section{Uji Homogenitas}

Pengujian homogenitas dipakai guna mengetahui data dari hasil penelitan memiliki nilai varian yang sama atau tidak. Dikatakan memiliki nilai versi yang sama atau nilai versi tidak berbeda (homogen) jika nilai signifikansi yaitu > 0,05 dan sebaliknya apabila nilai signifikansi yaitu $<0,05$ maka dapat dikatakan tidak memiliki nilai varian yang sama atau berbeda (tidak homogen).

Berdasarkan

homogenitas menggunakan aplikasi komputer bisa diketahui hasil nilai probabilitas variabel Keterikatan Karyawan (X) terhadap variabel Kinerja Karyawan (Y) 0,448 > 0,05 dan variabel Komitmen Kerja (Z) terhadap Kinerja Karyawan (Y) 0,072 lebih besar > 0,05 maka dapat disimpulkan bahwa varian atau dua lebih kelompok data adalah sama atau tidak berbeda (homogen).

\section{Analisis Jalur (Path Analisys)}

Dalam penelitian ini metode analisis yang dipakai ialah memakai metode analisis jalur atau yang lebih dikenal dengan Path Analysis. Menurut (Supriyanto \& Maharani, 2013, p. 74) mengatakan bahwasanya model ini untuk mengetahui pengaruh langsung ataupun tidak langsung seperangkat variabel bebas (eksogen) terhadap variabel terikat (endogen). Sedangkan menurut (Kuncoro \& Encos, 2008, p. 61) bahwasanya koefisien jalur (path) merupakan koefiseien regresi yang distandarkan yaitu koefisien regresi yang dihitung dari basis data yang sudah diatur dalam angka normal ( $Z$ - Score). Adapun analisis ini dibantu juga oleh program bantuan aplikasi komputer SPSS dengan ketetapan pengujian $\mathrm{F}$ terhadap nilai $\alpha=0,05$ atau $\mathrm{p}$ $\leq 0,05$ yang dimunculkan oleh kode (Sig $\mathrm{T})$ yang mana hal itu dipakai guna dapat mengetahui signifikansi pengaruh langsung dan tidak langsung dari variabel bebas terhadap variabel terikat (Supriyanto \& Maharani, 2013, p. 74).

\section{Pengaruh Keterikatan Karyawan (X) Terhadap Kinerja Karyawan (Y)}

Berdasarkan dari hasil pengujian menggunakan aplikasi komputer dapat simpulkan bahwasanya diketahui bahwa nilai jalur variabel Keterikatan Karyawan (X) terhadap Komitmen Kerja (Z) yaitu 
sebesar 0,669 serta diketahui nilai standar error 1 yaitu sebesar 0,742 .

Untuk mencari nilai standar error 1 yaitu memakai rumus:

$$
\begin{gathered}
e=\sqrt{1-r 2} \\
e=\sqrt{1-0,448} \\
e 2=0,742
\end{gathered}
$$

Keterangan :

e $\quad=$ Nilai standar error

$\mathrm{r}^{2}=\mathrm{r}$ square (terdapat dalam tabel model summary)

\section{Pengaruh Keterikatan Karyawan} (X) Terhadap Kinerja Komitmen Kerja (Z)

Berdasarkan hasil pengujian menggunakan aplikasi komputer diketahui bahwa nilai jalur variabel Keterikatan Karyawan (X) terhadap variabel Komitmen Kerja (Z) yaitu sebesar 0,686.Serta diketahui nilai signifikansi Keterikatan Karyawan (X) sebesar 0,00 < 0,05 berarti memiliki pengaruh yang signifikan terhadap Komitmen Kerja (Z).

\section{Pengaruh Komitmen Kerja (Z)}

Terhadap Kinerja Karyawan (Y)

Berdasarkan dari hasil perhitungan menggunakan aplikasi komputer dapat disimpulkan bahwasanya diketahui bahwa nilai jalur variabel Keterikatan Karyawan (X) terhadap variabel Kinerja Karyawan (Y) yaitu sebesar 0,746.Serta diketahui nilai standar error 2 yaitu sebesar 0,666.

Untuk mencari nilai standar error 3 yaitu memakai rumus:

$$
\begin{gathered}
e=\sqrt{1-r 2} \\
e=\sqrt{1-0,556} \\
e 2=0,666
\end{gathered}
$$

Keterangan :

e $\quad=$ Nilai standar error

$\mathrm{r}^{2}=\mathrm{r}$ square (terdapat dalam tabel model summary)
4. Pengaruh Keterikatan Karyawan (X) Terhadap Kinerja Karyawan (Y) Melalui Komitmen Kerja (Z)

Berdasarkan hasil perhitungan menggunakan aplikasi komputer dapat simpulkan bahwasanya diketahui bahwa nilai jalur variabel Keterikatan Karyawan (X) terhadap variabel Kinerja Karyawan (Y) melalui Komitmen Kerja (Z) yaitu sebesar 0,298 serta diketahui nilai standar error 2 yaitu sebesar 0,630 .

Untuk mencari nilai standar error 2 yaitu memakai rumus:

$$
\begin{gathered}
e=\sqrt{1-r 2} \\
e=\sqrt{1-0,603} \\
e 2=0,630
\end{gathered}
$$

Keterangan :

e $\quad=$ Nilai standar error

$\mathrm{r}^{2}=\mathrm{r}$ square (terdapat dalam tabel model summary)

Berdasarkan dari hasil perhitungan menggunakan aplikasi komputer diketahui nilai signifikansi variabel Keterikatan Karyawan $(\mathrm{X})$ sebesar 0,02 $<0,05$ berarti memiliki pengaruh yang signifikan terhadap Kinerja Karyawan (Y). Sedangkan, variabel Komitmen Kerja (Z) memiliki nilai signifikansi $0,00<0,05$ yang juga berarti memiliki pengaruh yang signifikan terhadap variabel Kinerja Karyawan (Y). 
Model Analisis Jalur

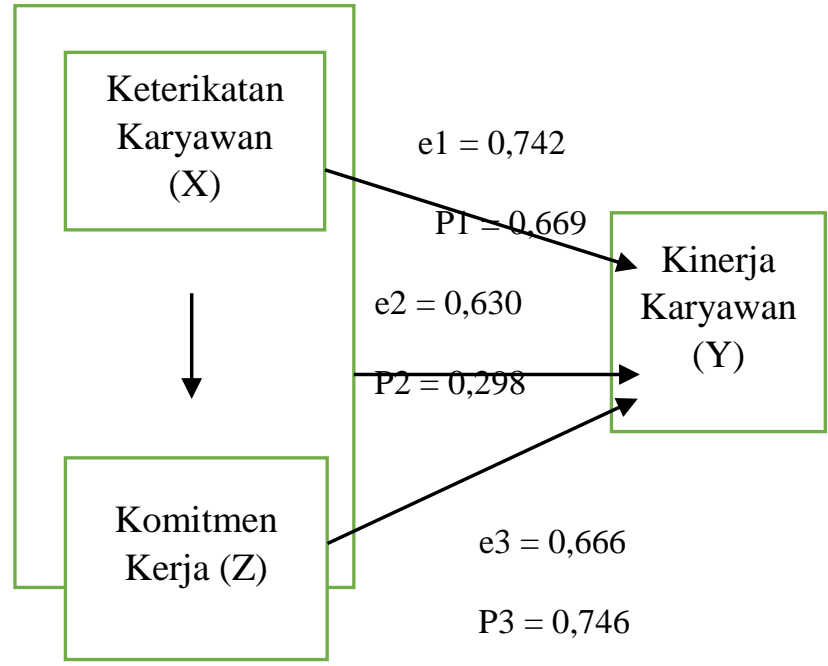

Sumber : Diolah Oleh Peneliti (2020)

Gambar 6

Model Analisis Jalur

Berdasarkan model analisis jalur dapat diketahui bahwa:

1. Besarnya nilai pengaruh langsung variabel Keterikatan Karyawan (X) terhadap variabel Kinerja Karyawan $(\mathrm{Y})=\mathrm{P}_{1}=0,669$

2. Sedangkan nilai pengaruh tidak langsung variabel Keterikatan

Karyawan (X) Melalui variabel Komitmen Kerja (Z) terhadap variabel Kinerja Karyawan $(\mathrm{Y})=\left(\begin{array}{lll}\mathrm{P}_{2} & \mathrm{x} & \mathrm{P}_{3}\end{array}\right)=$ $(0,298 \times 0,746)=0,222$

3. Nilai jumlah total pengaruh variabel Keterikatan Karyawan (X) terhadap variabel Kinerja Karyawan $(\mathrm{Y})=\mathrm{P}_{1}+$ $\left(\mathrm{P}_{2} \times \mathrm{P}_{3}\right)=0,669+0,222=0,891$

\section{Perhitungan Analisis Jalur}

Tabel 1

\begin{tabular}{cccc}
\multicolumn{4}{c}{ Perhitungan Analisis Jalur } \\
\hline Variabel & $\begin{array}{c}\text { Langsun } \\
\mathbf{g}\end{array}$ & $\begin{array}{c}\text { Tidak } \\
\text { Langsun } \\
\mathbf{g}\end{array}$ & Total \\
& & & \\
\hline $\begin{array}{c}(\mathbf{X}) \\
\text { Terhadap } \\
(\mathbf{Y})\end{array}$ & 0,669 & & - \\
\hline $\begin{array}{c}(\mathbf{Z}) \\
\text { Terhadap }\end{array}$ & 0,746 & - & \\
\hline
\end{tabular}

\begin{tabular}{cccc}
\hline$(\mathbf{Y})$ & & & \\
\hline$(\mathbf{X})$ & 0,298 & $0,298 \times$ & $0,669+$ \\
Terhadap & & $0,746=$ & $0,222=$ \\
$(\mathbf{Y})$ & & 0,222 & 0,891
\end{tabular}

Melalui (Z)

Sumber : Diolah Oleh Peneliti (2020)

\section{Pengujian Hipotesis \\ Uj T (Parsial)}

Berdasarkan hasil yang diperoleh dari perhitungan menggunakan aplikasi komputer diketahui nilai $\mathrm{t}$ hitung lebih besar dari pada nilai $\mathrm{t}$ tabel $(8,301>1,98861)$ maka dari itu Ho1 ditolak dan Ha1 diterima. Sehingga kesimpulan hipotesisnya adalah terdapat pengaruh Variabel Keterikatan Karyawan (X) terhadap Variabel Kinerja Karyawan (Y).

Berdasarkan hasil yang diperoleh dari perhitungan menggunakan aplikasi komputer diketahui nilai $\mathrm{t}$ hitung lebih besar dari pada nilai $\mathrm{t}$ tabel $(8,682>1,98861)$ maka dari itu $\mathrm{Ho} 2$ ditolak dan $\mathrm{Ha} 2$ diterima. Sehingga kesimpulan hipotesisnya adalah terdapat pengaruh Keterikatan Karyawan (X) terhadap Komitmen Kerja (Z).

Berdasarkan hasil yang diperloleh dari perhitungan menggunakan aplikasi komputer diketahui nilai $\mathrm{t}$ hitung lebih besar dari nilai $t$ tabel $(10,325>1,98861)$. Maka, Ho3 ditolak dan Ha3 diterima. Jadi untuk kesimpulan hipotesisnya adalah terdapat pengaruh variabel Komitmen Kerja (Z) terhadap variabel Kinerja Karyawan (Y).

\section{Uji F (Simultan)}

Berdasarkan hasil yang diperoleh dari perhitungan menggunakan aplikasi komputer diketahui nilai $\mathrm{F}$ hitung yaitu sebesar 63,880 dengan nilai $\mathrm{F}$ tabel yaitu 3,10 jadi nilai $F_{\text {hitung }}>F_{\text {tabel }}$ atau $63,880>$ 3,10 serta nilai signifikansi $0,000<0,05$. 


\section{Kesimpulan dan Saran}

Berdasarkan dari hasil penelitian, maka dapat disimpulkan bahwa :

1. Keterikatan Karyawan memiliki pengaruh positif dan signifikan terhadap Kinerja Karyawan PDAM Tirta Kahuripan Kabupaten Bogor yang artinya apabila semua karyawan memiliki keterikatan dalam bekerja dan terhadap perusahaan maka bisa memberikan kontribusi penuh guna kemajuan PDAM Tirta Kahuripan Kabupaten Bogor.

2. Keterikatan Karyawan memiliki pengaruh positif dan signifikan terhadap Komitmen Kerja PDAM Tirta Kahuripan Kabupaten Bogor yang artinya apabila semua karyawan memiliki komitmen dalam bekerja dan terhadap perusahaan, maka bisa memberikan kontribusi penuh guna tercapainya tujuan perusahaan.

3. Komitmen Kerja memiliki pengaruh positif dan signifikan terhadap Kinerja Karyawan PDAM Tirta Kahuripan Kabupaten Bogor yang artinya bahwa apabila semua karyawan memiliki Komitmen dalam bekerja dan Komitmen terhadap perusahaan maka akan meningkatkan hasil Kinerja Karyawan.

4. Keterikatan Karyawan memiliki pengaruh positif dan signifikan terhadap Kinerja Karyawan melalui Komitmen Kerja Karyawan PDAM Tirta Kahuripan Kabupaten Bogor yang artinya apabila semua karyawan memiliki Keterikatan dan Komitmen Kerja yang tinggi maka akan memberikan kontribusi penuh terhadap PDAM Tirta Kahuripan Kabupaten Bogor dalam bentuk Kinerja Karyawannya yang nanti akan dapat mendukung dalam proses pencapaian tujuan perusahaan yang sudah direncanakan.

\section{Saran Bagi Perusahaan}

1. Berdasarkan hasil penelitian Keterikatan Karyawan PDAM Tirta Kahuripan Kabupaten Bogor termasuk tinggi. Keterikatan pada karyawan sangat dibutuhkan karena karyawan yang terikat bisa mengatasi tuntutan tugas pekerjaannya dengan baik. Perusahaan sebaiknya membuat area lingkungan kerja yang bersih, nyaman, serta kondusif. Peningkatan area lingkungan kerja mempunyai tujuan membuat nyaman karyawan dalam bekerja, bisa dilakukan dengan memperbaiki / merubah sedikit interior kantor supaya menjadi lebih menarik, penggunaan fasilitas kantor yang lebih lengkap, serta meningkatkan hubungan komunikasi baik antara rekan kerja dan atasan supaya terciptanya kenyamanan dalam perusahaan khususnya dilingkungan kerja PDAM Tirta Kahuripan Kabupaten Bogor.

2. Berdasarkan hasil penelitian Komitmen Kerja pada PDAM Tirta Kahuripan Kabupaten Bogor termasuk tinggi. Komitmen Kerja sangat dibutuhkan sebab karyawan yang mempunyai komitmen kerja akan ikut melibatkan dirinya di dalam perusahaan dan tidak ada perasaan untuk meninggalkan perusahaan. Perusahaan sebaiknya membuat keterbukaan antara atasan dengan bawahan sehingga bisa terciptanya kesempatan karyawan untuk menyampaikan inovasi bagi kinerjanya yang bertujuan untuk kesuksesan perusahaan.

3. Berdasarkan hasil penelitian, Kinerja Karyawan PDAM Tirta Kahuripan 
Kabupaten Bogor termasuk tinggi. Kinerja Karyawan sangat dibutuhkan untuk mengoptimalkan kemajuan perusahaan. Perusahaan sebaiknya membuat standar operasional prosedur yang jelas serta penghargaan untuk karyawan yang mempunyai kinerja yang sangat baik dan maksimal serta tepat waktu didalam menuntaskan tugas pekerjaan, supaya karyawan lebih semangat, giat serta rajin dalam menyelesaikan tugas pekerjaannya dengan baik. Karena hasil kerja yang baik akan berpengaruh terhadap kinerja karyawan dan kinerja perusahaan.

\section{Saran Bagi Peneliti Berikutnya}

1. Penelitian ini memakai metode penelitian kuantitatif, disarankan bagi penelitian berikutnya memakai metode penelitian kualitatif.

2. Penelitian ini, pengaruh antar variabel diuji memakai analisis jalur, maka disarankan untuk penelitian berikutnya memakai uji analisis regresi berganda.

3. Berdasarkan hasil penelitian, disarankan untuk penelitian berikutnya memakai variabel yang berbeda, seperti kompensasi, stres kerja, kepemimpinan, loyalitas karyawan dan variabel lainya.

4. Apabila memakai variabel yang sama, maka disarankan penelitian berikutnya memakai alat ukur yang berbeda supaya bisa memberikan pemahaman serta pengetahuan yang luas mengenai Keterikatan Karyawan, Komitmen Kerja dan Kinerja Karyawan.

\section{Daftar Pustaka}

Arisca, G., Firdaus, M. A., \& Rinda, R. T. K. (2019). Pengaruh Kepuasan Kerja Dan Komunikasi Terhadap
Kinerja Karyawam. Jurnal Ilmu Manajemen Universitas Ibn Khaldun Bogor, Vol. 2 No.2, Hal 11-20.

Darna, N., \& Herlina, E. (2018). Memilih Metode Penelitian Yang Tepat: Bagi Penelitian Bidang Ilmu Manajemen. Jurnal Ekonologi: Jurnal Ilmu Manajemen Universitas Galuh Ciamis, 5 (1), 287-292.

Hadi, S. (2004). Analisis regresi. Penerbit Andi.

Imam, G. (2009). Aplikasi Multivariate dengan program SPSS. Semarang: Badan Penerbit Universitas Diponegoro.

Kuncoro, A., \& Encos, R. (2008). Analisis Jalur. Edisi-Ke, 2, 61-62.

Liana, Y., \& Irawati, R. (2014). Peran Motivasi, Disiplin Kerja terhadap Komitmen Karyawan dan Kinerja Karyawan pada Perusahaan Air Minum di Malang Raya. Jurnal Manajemen Dan Akuntansi, 3 (1).

Melina Taurisa, C., \& Intan, R. (2012). Analisis pengaruh budaya organisasi dan kepuasan kerja terhadap komitmen organisasional dalam meningkatkan kinerja karyawan (Studi pada PT. Sido Muncul Kaligawe Semarang). Jurnal Bisnis Dan Ekonomi, 19 (2).

Nurjanah, R., Rofaida, R., \& Suryana, S. (2016). Kepribadian Karyawan Dan Budaya Organisasi: Faktor Determinan Keterikatan Karyawan (Employee Engagement). Jurnal Manajemen, 20 (2), 310-324. 
Sugiyono, P. D. (2013). Metode penelitian. CV Alfabeta.

Supriyanto, A. S., \& Maharani, V. (2013). Metodologi Penelitian Manajemen Sumber Daya Manusia Teori, Kuesioner, dan Analisis Data. Cetakan II.

Trisnaningsih, S. (2001). Pengaruh Komitmen Terhadap Kepuasan Kerja Auditor: Motivasi Sebagai Variabel Intervening (Studi Empiris Pada Kantor Akuntan Publik di Jawa Timur). 